\title{
TINDAK PIDANA PEMBUNUHAN DENGAN CARA MEMOTONG-MOTONG MAYAT KORBAN DALAM PERSPEKTIF HUKUM DAN KRIMINOLOGI
}

\author{
Bagus Widyatmoko \\ Lembaga Bantuan Hukum dan Hak Asasi Manusia Malang \\ Email : denbagus100689@gmail.com
}

\begin{abstract}
Abstrak
Tindakan krimininalitas tidak hanya mengganggu ketentraman dan kenyaman terhadap kehidupan berbangsa dan bernegera, tetapi lebih dari itu kejahatan juga dapat menimbulkan kegelisahan dan rasa ketakutan yang lebih terhadap masyarakat secara umum. Terlebih dalam belakangan ini kasus-kasus kehajatan terus terjadi dan banyak mengalami peningkatan baik dari segi jumlah kasus ataupun dari jenis tindak pidana yang dilakukan oleh para pelaku, salah satunya adalah kasus pembunuhan yang disertai dengan memutilasi mayat korban hal ini tentu tergolong dalam kejahatan yang sangat sadis dan tidak manusiawi. Memutilasi mayat korban pembunuhan tentunya berbeda dengan pembunuhan biasa sehingga dalam penelitian ini dikemukakan bahwa pelaku mutilasi rata-rata dilatarbelakangi oleh karakter atau sifat bawaan manusia yang masuk dalam ketegori psikopat. Dengan demikian dari hasil penelitian ini diharapkan para pelaku dapat disadarkan sebelum melakukan tindak pidana pembunuhan yang disertai dengan mutilasi dengan cara memberikan penjatuhan pidana yang berat terhadap pelaku tindak pidana pembunuhan yang disertai dengan memutilasi mayat korban.
\end{abstract}

Kata kunci: Tindak Pidana, Mutilasi, Hukum dan Kriminologi.

\begin{abstract}
Acts of criminality not only disturb peace and comfort in the life of the nation and haste, but more than that crime can also cause more anxiety and fear of society in general. Especially in recent times cases of corruption have continued to occur and have experienced an increase in both the number of cases and the types of criminal acts committed by the perpetrators, one of which is a murder case accompanied by mutilating the victim's corpse, this is certainly a very sadistic crime. and inhuman. Mutilating the corpse of a murder victim is certainly different from ordinary murder so that in this study it is argued that the perpetrators of mutilation are on average motivated by human characters or traits that fall into the category of psychopaths. Thus, from the results of this study, it is hoped that the perpetrators can be made aware of before committing the crime of murder which is accompanied by mutilation by giving the imposition of a serious punishment against the perpetrator of the crime of murder accompanied by mutilating the body of the victim.
\end{abstract}

Keywords: Crime, Mutilation, Law and Criminology 


\section{Hurnal Negara dan $\mathcal{X}$ eadilan \\ p-ISSN 2302-7010 e-ISSN 2721-9801}

\section{PENDAHULUAN}

Kejahatan merupakan salah satu pertistiwa atau kejadian yang terjadi dan menguji masyarakat atau bangsa setua umur kehidupan manusia. Tidak ada masyarakat yang tidak diuji dengan kejahatan. Kalau kita mendatangi atau hidup di masyarakat mesti akan berhubungan dengan berbagai bentuk perilaku yang merugikan, yang salah satunya dikenal dengan kejahatan. ${ }^{1}$ Tindak pidana atau kejahatan mulai menjadi kata yang tidak asing dalam kehidupan suatu masyarakat. Ada sedikit perbuatan yang dinilai merugikan seperti menggangu dan merugikan sesama manusia sudah disebut sebagai tindak kejahatan. Masyarakat akhirnya gampang memberikan julukan pada seseorang yang sering berbuat onar dan menggangu orang lain dengan sebutan sebagai "orang jahat". Kejahatan menjadi realitas yang mengiringi keragaman perkembangan atau kepentingan di tengah masyarakat. $^{2}$

Kejahatan dapat diartikan secara kriminologis dan yuridis. Kejahatan dalam arti kriminologis yaitu perbuatan manusia yang menodai norma-norma dasar dari masyarakat. Hal ini dimaksudkan sebagai perbuatan unsur yang menyalahi aturan-aturan yang hidup dan berkembang di masyarakat. Kejahatan yuridis yaitu perilaku jahat atau perbuatan jahat dalam arti hukum pidana maksudnya bahwa kejahatan itu dirumuskan di dalam peraturan-peraturan pidana.

Salah satu perstiwa kriminalitas atau tindak pidana adalah mutilasi. Kasus seperti mutilasi ini juga disebut sebagai kejahatan yang menggmparkan, karena ada seseorang yang menjadi korbannya. Kasus mutilasi menjadi salah satu peristiwa kriminalitas yang membuat masyarakat ketakutan, apalagi kalau ada diantara keluarganya sudah lama tidak ada kabarnya, mereka mencoba mencari kabarkabar kepada pihak aparat kepolisian yang dikaitkan dengan mutilasi yang tidak atau belum teridentifikasi.

Belum lama ini kasus mutilasi juga menggemparkan di Malang Jawa Timur. Salah satu kasus mutilasi ternyata membuat masyarakat, khususnya aparat harus bekerja keras membongkarnya

Beberapa tahun lalu juga terjadi. Sebagai contoh kasus: saat masih menjabat Kepala Bidang Kedokteran Kesehatan Kepolisian Daerah Jawa Timur Komisaris Besar Rudy Herdisampurno telah memastikan identitas lima dari enam jenazah korban pembunuhan Verry Idham Henyansah alias Ryan. Kepastian itu didapat setelah Laboratorium DNA Bidang Kedokteran Kepolisian dan Pusat Kedokteran Kesehatan Mabes Polri telah menyelesaikan uji DNA atas lima jenasah tersebut. Hasil uji DNA itu dikirimkan ke Bidang Kedokteran Kesehatan Polda Jatim. Kelima korban itu sama persis dengan yang diperkirakan selama ini, yaitu Silvia Ramadhani Puteri, Nanik Hidayati (ibu Silvia), Agustinus Fitri Setiawan, M. Achsoni dan M. Zainul Abidin. Selain dari DNA keluarganya, identifikasi jenazah juga dilakukan berdasarkan temuan properti di tubuh korban, analisa gigi dan data antem mortem.

Properti yang ditemukan diantaranya bandul kalung di leher Silvia dan kuitansi pembelian cincin di Toko Emas Ramayana, Mojokerto di saku baju jenasah Achsoni. Sedangkan terhadap jenasah Mister X, Rudy mengaku kesulitan mengidentifikasi karena data properti yang ditemukan sudah hampir hancur. Data

\footnotetext{
${ }^{1}$ Suharianto, Perkembangan Kejahatan di Indoneia, Taman Baca Indonesia, Jakarta, 2015, hlm. 6

${ }^{2}$ Kusnanto, Kejahatan-Kejahatan Elitis, Hipress, Jakarta, 2016, hlm. 3.
} 


\section{$\mathcal{H}$ urnal Negara dan Keadilan \\ p-ISSN 2302-7010 e-ISSN 2721-9801}

properti yang masih dikenali hanya asesoris kalung kayu dan gelang karet di tubuh jenasah. Diantaranya adalah berjenis kelamin lakilaki, berusia 20-30 tahun, berasal dari ras Mongoloid dan keadaan giginya lengkap Jenasah enam orang korban itu digali polisi dari belakang rumah Ryan di Jatiwates, Jombang pada 28 Juli lalu. Silvia dan Nanik diperkirakan dibunuh pada April 2008, Agustinus pada Agustus 2007, Zainul pada Januari 2008, Achsoni pada November 2007 dan Mister X pada akhir 2006. ${ }^{3}$

Kasus tersebut menggambarkan tentang seriusnya kasus mutilasi. Kejahatan akhirnya seperti mutilasi mulai menjadi kata yang tidak asing dalam kehidupan suatu masyarakat. Ketika kejahatan ini awal terbongkar, maka masyarakat langsung memberikan reaksi luar biasa terhadap pelaku. Kejahatankejahatan yang bersifat atau berpola sangat mengerikan, mestilah mengundang reaksi publik yang bersifat cepat karena sebenarnya hal ini sebagai bentuk kutukan sosial. $^{4}$

Kondisi ini terus berkembang. Suatu kenyataan yang tidak bisa dipungkiri, bahwa kejahatan seperti mutiasi tersebut merupakan kenyataan yang terjadi dalam kehidupan manusia di dalam proses interaksi sosial. Kalau tidak melalui suatu interaksi, barangkali kejahatan mutilasi tidak akan pernah terjadi atau menimpa seseorang atau beberapa orang.

Kejahatan terus berkembang seiring dengan perkembangan peradaban manusia, dengan kualitas dan kuantitasnya kompleks dengan variasi modus operandinya. JE Sahetapy telah menyatakan dalam tulisanya, kejahatan erat kaitanya dan bahkan menjadi sebagian dari hasil budaya itu sendiri. Ini berarti semakin tinggi tingkat budaya dan semakin modern suatu bangsa, maka semakin modern pula kejahatan itu dalam bentuk, sifat dan cara pelaksanaanya. ${ }^{5}$

Gambaran itu menunjukkan, bahwa dunia kejahatan bukanlah dunia yang asing bagi kehidupan manusia dan masyarakat, tetapi sebagai dunia yang dekat hubungannya dengan perkembangan masyarakat. Semakin berkembang suatu masyarakat, ada kecenderungan semakin berkembang pula kejahatan. Perkembangan kejahatan dalam suatu masyarakat, adalah cermin dari kenyataan kehidupan masyarakat.

Kriminalitas merupakan kenyataan yang terjadi di setiap masyarakat dan bangsa. Dimana ada masyarakat di situ ada kejahatan. Kejahatan adalah sisi lain dari wajah atau potret masyarakat. Membahas kejahatan berarti membahas sisi lain yang terdapat dalam kehidupan masyarakat.

Suatu realitas yang tidak bisa dipungkiri, bahwa salah satu problem yang mengakibatkan kehidupan masyarakat tidak tenang, tidak harmonis, tidak nyaman, dan terjadi banyak kerugian baik harta maupun nyawa adalah problem kejahatan. Mutilasi merupakan problem kejahatan yang membuat masyarakat mengalami ketakutan dan penderitaan psikologis. Karean siapapun tidak akan ada seserang yang mau menjadi korban demikian.

Mutilasi telah hadir menjadi bagian dari kehidupan riil masyarakat, atau dimana ada masyarakat atau manusia di situ ada kejahatan, atau mutilasi

${ }^{3}$ Ahsin Ghaffar, Membedah Kejahatan yang Berkembang di Abad 21, Sanggar Baca, Surabaya, 2015, hlm. 45.

${ }^{4}$ Kusnanto, Kejahatan-Kejahatan Elitis, Hipress, Jakarta, 2016, hlm. 23

${ }^{5}$ Marwan Hamid, Mengajak Masyarakat Melawan Kejahatan, LPPKS, Jakarta, 2009. hlm.7. 


\section{Zurnal Negara dan $\mathcal{X}$ eadilan \\ p-ISSN 2302-7010 e-ISSN 2721-9801}

merupakan bagian nyata dari kehidupan masyarakat. Hal ini seperti pepatah hukum yang menyebutkan dimana ada masyarakat di situ ada hukum. Eksistensi kejahatan menjadi cermin kehidupan masyarakat. Kejahatan tidak akan mungkin ada tanpa adanya masyarakat. Kejahatan mutilasi tidak akan pernah ada kalau tidak ada masyarakat.

Di tengah masyarakat itulah kejahatan menunjukkan bentuk nyata dan ragamnya sesuai dengan perkembangan masyarakat itu sendiri. Masyarakat memang tidak menginginkan kehidupannya serba tidak nyaman dan tidak harmonis, akan tetapi masyarakat juga seringkali tidak mampu mencegah atau menanggulangi kriminalitas yang berdampak buruk terhadap dirinya, karena lahirnya atau terjadinya dan maraknya kejahatan adalah terkait dengan pola hidup dalam berbudaya, berekonomi, dan berinteraksi sosial yang mendorong terjadinya tindak kejahatan. Kejahatan atau tindak pidana mutilasi juga merupakan bagian dari resiko pergaulan hidup di masyarakat. Kejahatan mutilasi tidak akan pernah terjadi kalau di masyarakat tidak terbentuk berbagai model pergaulan hidup. ${ }^{6}$ Pergaulan hidup yang bersfat khusus atau jalinan tertentu yang bersifat lebih tetutup bisa membuka rang terjadinya kejahatan tertentu pula. ${ }^{7}$

\section{PEMBAHASAN}

\section{Kajian Hukum Indonesia Terhadap Tindak Pidana Pembunuhan Dengan Cara Memotong-Motong Mayat Korban}

Tindak Pidana mutilasi sampai saat ini, baik dalam KUHP maupun peraturan perundang-undangan lainnya, diasumsikan masih belum terdapat ketentuan yang mengatur secara tegas dan jelas mengenai hal tersebut, untuk menjawab perihal pasal-pasal KUHP yang dikaitkan dengan tindak pidana mutilasi, sehingga dapat dicapai tujuan dari asas legalitas, yakni menegakkan kepastian hukum dan mencegah kesewenang wenangan penguasa. ${ }^{8}$

Dalam KUHP perbuatan mutilasi merujuk pada pembunuhan berencana (Pasal 340 KUHP) atau pembunuhan yang diikuti, disertai, atau didahului oleh suatu perbuatan pidana (Pasal 339 KUHP). Bisa juga hanya merujuk pada pembunuhan biasa (Pasal 338). Dalam dua putusan Mahkamah Agung yang disertai kekerasan memutilasi bagian-bagian tubuh korban, hakim sama sekali tak menyinggung istilah mutilasi.

Masih bersumber dari artikel yang sama, dalam Putusan Mahkamah Agung Nomor 24 PK/Pid/2003, hakim hanya menyatakan terdakwa Siswanto alias Robot bersalah melakukan tindak pidana pembunuhan berencana. Dalam kasus mutilasi yang lebih sadis, yakni perkara pembunuhan korban Soleh bin Zaidan di Musi Banyuasin Sumatera Selatan (terakhir dengan Putusan Mahkamah Agung (MA) Nomor 108 PK/Pid/2007), terdakwa Ibrahim bin Ujang dihukum karena secara bersama-sama melakukan pembunuhan berencana. Padahal para pelaku telah melakukan mutilasi terhadap tubuh korban dan menguburkan korban tanpa bagian kepala.

Kalau bagaimana hukumnya jika perbuatan mutilasi itu tidak diawali dengan membunuh korban, tapi hanya memotong-motong mayat? Bisakah dijerat

Hlm. 27

${ }^{6}$ Marwan Hamid, Mengajak Masyarakat Melawan Kejahatan, LPPKS, Jakarta, 2009.

${ }^{7}$ Kusnanto, Op.Cit, hlm. 40

${ }^{8}$ Teguh Prasetyo, Op.Cit, hlm. 38 


\section{Jurnal Negara dan $\mathcal{X}$ eadilan \\ p-ISSN 2302-7010 e-ISSN 2721-9801}

dengan pasal pengrusakan benda? Atau pasal soal pencurian benda? R. Soesilo dalam bukunya Kitab Undang-Undang Hukum Pidana (KUHP) Serta KomentarKomentarnya Lengkap Pasal Demi Pasal (hal 150) menjelaskan antara lain bahwa mayat bukanlah suatu harta benda atau barang milik orang. Oleh karena itu, pasal tentang "pencurian" (Pasal 362 KUHP) atau pasal tentang "merusak barang" (Pasal 406 KUHP) dan sebagainya tidak berlaku dalam hal ini. Namun, pendapat berbeda diungkapkan oleh Is Heru Permana, Ketua LBH Kosgoro Kabupaten Banyumas dalam artikel Curi Mayat Bisa Dihukum 7 Tahun yang kami akses dari laman Suara Merdeka, media berita Perekat Komunitas Jawa Tengah. Ia menjelaskan bahwa dalam hukum pidana mayat manusia itu milik ahli warisnya, sehingga orang yang mengambil mayat manusia secara melawan hukum berarti mengambil mayat itu dari pemiliknya, yaitu ahli warisnya. Berarti ia melakukan pencurian mayat sebagaimana diatur dalam Pasal 362 KUHP (Sudikno, 1999: 118, Putusan HR tanggal 25 Juni 1946 dalam Algra, Rechtsingang, hal 69). Jadi ada kemungkinan, pelaku bisa dijerat pasal pencurian.

Kemungkinan lain, jika perbuatan memutilasi mayat tersebut didahului dengan perbuatan mengeluarkan mayat dari kuburan dengan melawan hak (tidak mempunyai hak untuk melakukan tindakan tersebut); dapat diancam dengan Pasal 180 KUHP: "Barang siapa dengan sengaja dan dengan melawan hak mengeluarkan mayat dari kuburan atau mengambil atau memindahkan atau mengangkat mayat yang sudah dikeluarkan itu, dihukum penjara selama-lamanya satu tahun empat bulan atau denda sebanyak banyaknya Rp. $4.500 .^{9}$

Kasus mutilasi di Indonesia seperti tiada henti di negeri ini. Belum hilang dari ingatan mutilasi yang dilakukan oleh Ryan beberapa tahun yang lalu, kini khalayak dikejutkan lagi oleh kasus serupa yang lebih dahsyat, termasuk yang terjadi Malang

Peristiwa yang diantaranya pernah menggemparkan di Indonesia dengan tersangka pelaku, Baekuni alias Babe, diduga membunuh tujuh anak jalanan usia di bawah 12 tahun, yang empat di antaranya dimutilasi. Yang menambah seram, si Babe, gay usia tengah baya ini, pengidap paedofilia dan nekrofilia, suka berhubungan seks dengan mayat. Kasus ini menunjukkan bahwa kejahatan makin lama kian sadistis.

Kejahatan mutilasi merupakan bentuk tindak pidana yang berhubungan dengan masalah nyawa dan badan. tindak pidana terhadap nyawa dan badan. Sedangkan yang dimaksud di sini adalah tindak pidana yang akibatnya berkaitan dengan nyawa (hilangnya nyawa), badan, kehormatan atau nama baik atau yang berkaitan dengan kesulitan.65 Dalam Pasal 338 KUHP disebutkan: Barang siapa sengaja merampas nyawa orang lain, diancam karena pembunuhan, dengan pidana penjara paling lama lima belas tahun. ${ }^{10}$

Menurut Sunardi dan Fanny Tanuwijaya (2001: 2), bahwa Pasal 338 KUHP sering dikatakan sebagai pembunuhan biasa atau pembunuhan dalam bentuk pokok. Yang dimaksud ialah bahwa pasal 338 merupakan bentuk dasar dari tindak pidana pembunuhan yang dikenal dalam hukum pidana. Sedangkan tindak pidana pembunuhan selain dari yang diatur dalam pasal 338 merupakan bentuk pembunuhan yang diperingan atau diperberat kalau kita lihat dari berat

\footnotetext{
${ }^{9} \mathrm{https} / / / \mathrm{www} \cdot$ hukumonline.com/klinik/detail/ulasan/lt567ac0977c701/jerat-pidanapelakumutilasi-dan-pemerkosa-mayat/, akses 15 Oktober 2019

${ }^{10}$ Sunardi dan Fnny Tanuwijaya, Op.cit, hlm. 1
} 


\section{Zurnal Negara dan $\mathcal{X}$ eadilan \\ p-ISSN 2302-7010 e-ISSN 2721-9801}

ringan

ancaman pidananya. Oleh sebab itu, apabila ada tindakan pidana pembunuhan, ${ }^{11}$ maka makna atau arti dari pembunuhan dimaksud haruslah sesuai dengan sebagaimana yang diatur (dimaksud) dalam Pasal 338 KUHP.

Kalau kita simak bunyi pasal 338 KUHP, maka inti dari tindak pidana pembunuhan itu adalah "sengaja menghilangkan atau merampas nyawa orang lain'. Sengaja yang di dimaksud ialah hilangnya nyawa, merupakan hal yang dituju, dikehendaki, dimaksud atau dapat dibayangkan oleh pelaku. Pengertian kesengajaan itu bisa dilihat dari wills teori dan voorstilling teori sedangkan bentuknya bisa kesengajaan sebagai maksud, kesengajaan dengan sadar akan kepastian atau kesengajaan dengan sadar akan kemugkinan. Tidak ada pembunuhan bila matinya (meinggalnya) korban bukan hal yang dituju, dimaksud, dikehendaki, atau dapat dibayangkan oleh pelaku.

Uraian diatas menunjukkan, bahwa sesuai dengan kajian hukum di Indonesia, tindak pidana atau kejahatan mutilasi telah diatur dalam berbagai peraturan perundang-undangan di Indonesia. Dalam KUHP (Kitab Undangundang Hukum Pidana), mutilasi sudah diatur di dalamnya, yang beberapa pasal yang digunakan menjerat pelakunya diantaranya pasal 338, 340 KUHP (ketentuan tentang tindak pidana pembunuhan). Sedangkan norma hukum lain yang mengaturnya diantaranya bisa UU Nomor 15 Tahun 2003 tentang Penangggulangan Tindak Pidana Terorisme (sekarang memang sudah diperbarui,tetapi untuk ketentuan ini tidak ada perubahan) yang berkenaan dengan masalah pembunuhan (mutilasi) yang ditujukan untuk menciptakan dan menyebarkan ketakutan di masyarakat, dan Pasal 8 UU Nomor 26 Tahun 2000 tentang Pengadilan HAM, khususnya yang mengatur masalah tindak pidana pembunuhan yang di dasari oleh motif penghancuran etnis, menghabisi sekelompok masyarakat, atau adanya dugaan kalau kejahatan pembunuhan yang dilakukan seseorang atau sekelompok orang merupakan bagian dari rencana yang sistematik dan adanya modus memperluas ketakutan di masyarakat.

Berdasarkan hal itu, maka tindak pidana atau kejahatan mutilasi merupakan kejahatan yang serius, sehingga diharapkan bagi aparat penegak hukum untuk meningkatkan profesionalisme dalam menangani masalah atau kasus-kasus kejahatan mutilasi, sehingga masyarakat bisa lebih cepat atau lebih mudah mendapatkan informasi mengenai hasil kerjanya yang memperjelas kedudukan pelaku atau korbannya. Peran penegak hukum akan menentukan hasil pemeriksaan tindak pidana atau kejahatan pembunuhan dengan cara memutilasi atau memotong-motong mayat korban.

Apapun alasannya yang dikembangkan mengenai pembunuhan dengan cara memutilasi atau memotong-motong mayat korban, seharusnya pelaku tindak pidana ini dijerat dengan hukuman mati layaknya apa yang diatur dalam Pasal 340 KUHP

(tentang pembunuhan berencana), aparat penegak hukum diharapkan dapat menafsirkan dan mempersamakan kejahatan ini dengan kejahatan pembunuhan berencana walaupun dalam melakukannya setelah si korban mati duluan. mengingat bahwa pengaturan dan batasan pengertian tentang kejahatan ini tidak dijelaskan secara spesifik dan tegas di dalam Undang-undang Hukum Pidana Indonesia, atau belum

${ }^{11}$ Ibid, 


\section{$\mathcal{H}$ urnal Negara dan Keadilan \\ p-ISSN 2302-7010 e-ISSN 2721-9801}

adanya aturan yang menyebutnya secara tegas terkait dengan kasus mutilasi korban tersebut.

\section{Tindak Pidana Pembunuhan dengan Mutilasi korban dalam perspektif Kriminologi}

Kejahatan terhadap jiwa seseorang menimbulkan akibat mati, akibat matinya seseorang ini dilarang dan diancam dengan hukuman oleh undangundang. Istilah tindak pidana dalam bahasa Belanda dapat disebut sebagai "strafbaarfeit" yang berarti suatu perbuatan yang menjadikan pelakunya dipidana. Pengertian tindak pidana adalah perbuatan atau tindakan melawan hukum yang berlaku, baik itu pelanggaran atau kejahatan yang dapat dituntut dengan hukum pidana atau ketentuan peraturan perundang-undangan. ${ }^{12}$

Berbicara mengenai kejahatan khususnya pembunuhan, dahulu orang membunuh dengan cara yang sederhana sehingga kasus pembunuhan mudah terungkap oleh aparat kepolisian namun, seiring dengan perkembangan masyarakat dan ilmu pengetahuan, tindak kejahatan pembunuhan pun mengalami perkembangan yang diikuti dengan cara yang beragam mulai dari cara yang sederhana sampai dengan cara yang sadis dengan berbagai motif yang berbedabeda. Terkadang pembunuhan juga dilakukan dengan cara yang keji seperti disiksa lebih dahulu, dibakar dan bahkan di mutilasi. Adrianus Meliala, yang merupakan kriminolog Universitas Indonesia (UI) berpendapat dari sisi kriminologi, secara definitif yang dimaksud dengan mutilasi adalah terpisahnya anggota tubuh yang satu dari anggota tubuh yang lain oleh sebab yang tidak wajar. ${ }^{13}$

Mutilasi merupakan wujud dari tidak kekejaman atau kekerasan yang dilakukan manusia yang satu terhadap manusia lainnya. Oleh karena itu, kajian awal secara kriminologis, mutilasi dapat dianalisis dari sudut tindak kekerasan lebih dulu.

Berdasarkan bentuknya, kekerasan dapat digolongkan menjadi kekerasan fisik, psikologis, dan struktural:

1. Kekerasan fisik yaitu kekerasan nyata yang dapat dilihat, dirasakan oleh tubuh. Wujud kekerasan fisik dengan menghilangkan rasa kesehatan atau kemampuan normal tubuh, sampai pada penghilangan nyawa seseorang. Contoh penganiayaan, pemukulan,pembunuhan, dan lain-lain.

2. Kekerasan psikologis yaitu kekerasan yang memiliki sasaran pada rohani atau jiwa sehingga dapat mengurangi bahkan menghilangkan kemampuan normal jiwa. Contoh kebohongan, indoktrinasi, ancaman, dan tekanan.

3. Kekerasan struktural yaitu kekerasan yang dilakukan oleh individu atau kelompok dengan menggunakan sistem, hukum, ekonomi, atau tata kebiasaan yang ada di masyarakat. Oleh karena itu, kekerasan ini sulit untuk dikenali. Kekerasan struktural yang terjadi dapat menimbulkan ketimpangan pada sumber daya manusia, baik berupa pendidikan, pendapatan, kepandaian, keadilan, serta wewenang untuk mengambil keputusan. Situasi ini dapat memengaruhi fisik dan jiwa seseorang. Biasanya negaralah yang bertanggung jawab untuk mengatur kekerasan structural karena hanya negara yang memiliki kewenangan serta kewajiban resmi untuk mendorong pembentukan

${ }^{12}$ Sudarto, Hukum Pidana Indonesia. Semarang: Yayasan Sudarto Fakultas Hukum UNDIP. 1990. hlm. 39.

${ }^{13}$ Adrianus Meliala. Kriminologi Tindak Pidana. Jakarta: Gramedia Cipta. 2006. hlm.5 


\section{Zurnal Negara dan $\mathcal{X}$ eadilan \\ p-ISSN 2302-7010 e-ISSN 2721-9801}

atau perubahan struktural dalam kondisi masyarakat. Misalnya, terjangkitnya penyakit kulit di suatu daerah akibat limbah pabrik di sekitarnya atau hilangnya rumah oleh warga Sidoarjo karena lumpur panas Lapindo Brantas. Secara umum korban kekerasan struktural tidak menyadarinya karena system yang menjadikan mereka terbiasa dengan keadaan tersebut.

Sedangkan kekerasan berdasarkan pelakunya, kekerasan dapat digolongkan menjadi dua bentuk, yaitu sebagai berikut:

1. Kekerasan individual adalah kekerasan yang dilakukan oleh individu kepada satu atau lebih individu. Contoh pencurian, pemukulan, penganiayaan, dan lain-lain.

2. Kekerasan kolektif adalah kekerasan yang dilakukan oleh banyak individu atau massa. Contoh tawuran pelajar,bentrokan antardesa konflik Sampit dan Poso, dan lain-lain.

Menurut teori psikoanalisa dari Sigmund Freud (1956-1939), bahwa kriminalitas menghubungkan delinquent dan perilaku criminal dengan suatu "conscience" yang baik dia begitu menguasai sehingga menimbulkan perasaan bersalah atau ia begitu lemah sehingga tidak dapat mengontrol dorongandorongan si individu, dan bagi suatu kebutuhan yang harus dipenuhi segera. Sigmund freud, penemu sari Psychoanaliysis, ia berpendapat bahwa kriminalitas mungkin hasil dari "an overactive conscience" yang menghasilkan perasaan bersalah yang berlebih. Freud menyebutkan bahwa mereka yang mengalami atau memiliki perasaan bersalah yang tak tertahankan akan melakukan kejahatan dengan tujuan agar ditangkap dan dihukum. Begitu mereka dihukum maka perasaan bersalah mereka akan mereda. Seseorang melakukan perilaku terlarang karena hati nurani, atau super egonya begitu lemah atau tidak sempurna sehingga egonya tidak mampu megontrol dorongan-dorongan dari ide. Kerena super egonya intinya merupakan suatu citra orang tua yang begitu mendalam, terbangun ketika si anak menerima sikap-sikap dan nilai-nilai moral orang tuanya, maka selanjutnya apabila ada ketiadaan citra seperti itu mungkin akan melahirkan ide yang tidak terkendali dan berikutnya delequency.

Dalam kajian perbandingan antara kajian hukum dengan kriminologi terdapat persamaan dan perbedaan diantara keduanya. Dalam kajian hukum, mutilasi sudah jelas dikategorikan sebagai tindak kejahatan. Kajian ini sama dengan kajian kriminologi, yang obyek kajiannya juga kejahatan, diantaranya mutilasi. Keduanya juga sama-sama mengkaji masalah perilaku manusia yang melanggar norma-norma hukum.

Perbedaannya, dalam kajian hukum tidak memandang dari akar penyebab seseorang melakukan mutilasi, sedangkan dalam kajian kriminologi, titik tekan kajiannya pada aspek latar belakang atau faktor penyebab terjadinya mutilasi. Konteks terjadinya pembunuhan dengan mutilasi di atas lebih ditandai oleh adanya semacam "peranan korban" dalam mencetuskan kekerasan, seperti cara bergaul yang mengundang kecemburuan, mengajukan tuntutan yang sulit dipenuhi atau meminta dinikahi pelaku. Beberapa riset kriminologi membuktikan tentang cukup tingginya frekuensi pembunuhan terhadap perempuan yang dilatarbelakangi oleh pertengkaran yang sebenarnya cukup sepele, ketidakakuran dalam pernikahan atau pesengketaan seksual. Dengan begitu, mutilasi merupakan ungkapan emosionalitas yang diwujudkan 


\section{$\mathcal{H}$ urnal Negara dan Keadilan \\ p-ISSN 2302-7010 e-ISSN 2721-9801}

dengan kekejaman luar biasa, terutama terhadap korban yang tak terlindungi, karena keluarganya jauh atau sudah dianggap mandiri di luar tanggung jawab keluarga.

Oleh karena itu, pelaku adalah orang biasa maka modus operandinya pun tidak terlalu rumit atau tidak melalui perencanaan yang rinci, sehingga tak jarang meninggalkan jejak yang dapat ditelusuri polisi ataupun mengabaikan adanya saksi-saksi yang di kemudian hari ternyata dapat memberikan informasi tentang pelaku.

Selain itu, kajian kriminologi dalam kasus mutilasi akan menjadi bahan pertimbangan bagi kalangan penegak hukum dalam menangani atau membongkat posisi kasusnya. Secara yuridis, mutilasi dapat dikategorikan sebagai perbuatan yang melanggar hukum, namun belum tentu bisa dipertanggungjawabkan secara hukum bilamana kasus yang ditanganinya ini, seseorang yang melakukannya ternyata mengalami kelainan kejiwaan, atau menurut keterangan ahli, apa yang diperbuatnya terbukti sebagai akibat ketidaknormalan psikologis atau kejiwaannya.

Hal itu menunjukkan, bahwa secara kriminologis dukungan masyarakat akan

membuat penyelesaian kasus-kasus yang ditangani oleh aparat yang berwajib lebih mudah ditangani atau terbongkar. Hal ini kembalinya juga kepada masyarakat, yakni masyarakat akan diuntungkan oleh partisipasi yang dilakukannya, seperti keberanian memberikan kesaksian dalam proses pemeriksaan. Partisipasi masyarakat menentukan upaya pencegahan maupun penanggulangan.

Dapat dikonklusikan, bahwa dari akar penyebab kejahatan mutilasi, ada pakar yang menyebutnya, bahwa pelaku mengalami kelainan psikologis sehingga dirinya menjadi psikopat atau berkepribadian abnormal. Ada lagi pakar yang menyebut, bahwa tindak kejahatan mutilasi lebih disebabkan adanya unsur atau faktor balas dendam yang sangat mendalam kepada korban. Korban dianggap sebagai seseorang yang pantas mati dengan cara-cara yang mengerikan, sehingga pelaku menganggap kalau pembunuhan yang dilakukan haruslah dengan cara-cara keji. Ada pula yang menyebutkan, kalau tindak kejahatan mutilasi lebihdisebabkan oleh keinginan pelaku menghilangkan jejak atau bekas-bekas yang dimungkinkan akan dijerat oleh aparat yang berwajib. Sedangkan dari segi modus operandinya bermacam-macam atau bersifat kasuistik, yakni sesuai dengan masing-masing kasus pembunuhannya. Ada yang dilakukan dengan rencana yang matang dimana pembunuhan dengan cara dipotong-potong itu sudah disesuaikan dengan rencana sebelumnya, yang rencana ini sudah menghitung kemungkinan keberhasilannya, sedangkan cara lain dilakukan oleh pelaku secara spontaanitas atau begitu tiba-tiba atau pada saat setelah pembunuhan dilakukan.

Terlepas dari semua hal itu, kejahatan mutilasi kerap sekali terjadi dilakukan oleh orang-orang yang memang mengalami depresi dan gangguan kejiwaan, bahwa dengan tidak memotong-motong tubuh korbannya ,pelaku sering sekali tidak puas untuk menyelesaikan kejahatannya. Kalangan ahli tidak seragam dalam melihat prilaku mutilasi, karena motiv dan karakter prilaku pelakunya memang beragam. Tapi banyak yang melihat tindakan ini termasuk kelainan, prilaku Psikopat. Pelaku mutilasi adalah orangorang yang tidak memiliki suara hati dan cenderung mengalami gangguan jiwa. 


\section{Hurnal Negara dan $\mathcal{X}$ eadilan \\ p-ISSN 2302-7010 e-ISSN 2721-9801}

Mutilasi, adalah tragedi anak manusia. Pelakunya, juga adalah musuh peradaban manusia, karena tak memiliki perasaan dan belas kasih. Tak difikirkan bagaimana keluarga korban harus menanggung luka perasaan karenanya. Semoga hukum masih berpihak pada mereka yang kini tak punya pilihan kecuali mengharap, keadilan masih ditegakkan untuk mereka.

\section{PENUTUP}

Dalam kajian hukum di Indonesia tentang kedudukan tindak pidana pembunuhan dengan memotong-motong mayat korban atau menyebutkan, bahwa ada banyak norma hukum yang sudah mengatur tindak pidana pembunuhan, termasuk mutilasi. Tindak pidana mutilasi telah diatur dalam berbagai peraturan perundang-undangan di Indonesia. Dalam KUHP (Kitab Undang-undang Hukum Pidana), diantaranya pasal 338, 340 KUHP (ketentuan tentang tindak pidana pembunuhan). Sedangkan norma hukum lain yang mengaturnya diantaranya bisa UU Nomor 15 Tahun 2003 tentang penangggulangan tindak pidana terorisme yang berkenaan dengan masalah pembunuhan (mutilasi) yang ditujukan untuk menciptakan dan menyebarkan ketakutan di masyarakat, dan Pasal 8 UU Nomor 26 Tahun 2000 tentang Pengadilan HAM.

Dalam kajian kriminologi tentang tindak pidana pembunuhan dengan memotong-motong mayat korban menyebutkan atau menggariskan pada pembahasan masalah faktor-faktor penyebab terjadinya tindak pidana mutilasi dan modus operandi kejahatan atau tindak pidana mutilasi, khususnya yang terjadi di Indonesia. Dari akar penyebab kejahatan mutilasi, ada pakar yang menyebutnya, bahwa pelaku mengalami kelainan psikologis sehingga dirinya menjadi psikopat atau berkepribadian abnormal. Ada lagi pakar yang menyebut, bahwa tindak kejahatan mutilasi lebih disebabkan adanya unsuratau faktor balas dendam yang sangat mendalam kepada korban. Korban dianggap sebagai seseorang yang pantas mati dengan cara-cara yang mengerikan, sehingga pelaku menganggap kalau pembunuhan yang dilakukan haruslah dengan cara-cara keji. Ada pula yang menyebutkan, kalau tindak kejahatan mutilasi lebih disebabkan oleh keinginan pelaku menghilangkan jejak atau bekas-bekas yang dimungkinkan akan dijerat oleh aparat yang berwajib. Sedangkan dari segi modus operandinya bermacammacam atau bersifat kasuistik, yakni sesuai dengan masing-masing kasus pembunuhannya.

\section{Peraturan Perundang-undangan}

\section{DAFTAR PUSTAKA}

Undang-undang Dasar Negara Republik Indonesia Tahun 1945

Kitab Undang-undang Hukum Pidana (KUHP)

Undang-Undang Nomor 26 Tahun 2000 Tentang Pengadilan HAM

Buku

Abdillah Hadi, Perkembangan Pola-Pola Kejahatan di Indonesia, Visimedia Indonesia, Jakarta, 2015.

Abdul Syani, Sosiologi Kriminalitas, Bina Aksara, Bandung, 1987. 


\section{$\mathcal{H}$ urnal Negara dan Keadilan \\ p-ISSN 2302-7010 e-ISSN 2721-9801}

Abdul Wahid, Kriminologi dan Kejahatan Kontemporer, Lembaga Penerbitan Fakultas Hukum Unisma, Malang, 2002,

Adami Chazawi. Kejahatan Terhadap Tubuh dan Nyawa. Rajawali Pers. Jakarta. 2000.

Ahmad Fauzan, Anak Indonesia Menghadapi Kejahatan Mutakhir, Gerbang Indonesia, Jakarta, 2008.

Ahmad Harianto, Perkembangan Kejahatan Psikologis, Pelita Media, Bandung, 2008

Ahsin Ghaffar, Membedah Kejahatan yang Berkembang di Abad 21, Sanggar Baca, Surabaya, 2015.

Adrianus Meliala. Kriminologi Tindak Pidana. Jakarta: Gramedia Cipta. 2006.

Qirom Syamsudin dan E. Sumaryono, Kejahatan Anak, Suatu Tinjauan Psikologi, Liberty, Yogyakarta, 1980.

Arief Gosita, Masalah Korba Kejahatan Kumpulan Karangan, Akademika Pressindo, Jakarta, 1993.

B. Bosu, Kriminologi, Usaha Nasional, Surabaya, .1982

CST. Kansil, Pengantar Ilmu Hukum dan Tata Hukum Indonesia, Balai Pustaka, Jakarta, 2000.

Gilin Grosth. Pengantar Ilmu Bedah Anestesi. Yogyakarta: Prima Aksara, 2004.

Hanif Syakir, Kebersamaan Menanggulangi Kejahatan di Negara Berkembang, Mahita Maju, Solo, 2015.

Hary Saherodji, Pokok-pokok Kriminologi, Aksara baru, Jakarta, 1980.

J.E. Sahetapy, Bungai Rampai Viktimisasi, Eresco, Bandung, 1995

Kartini Kartono, Pathologi social, CV Rajawali, Jakarta, 2001.

Kusnanto, Kejahatan-Kejahatan Elitis, Hipress, Jakarta, 2016.

Leden Marpaung. Tindak Pidana Terhadap Nyawa dan Tubuh. Sinar Grafika; Jakarta, 2000.

Made Darma Weda, Kriminologi, Rajagrafindo Persada, Jakarta, 1996.

Marwan Hamid, Mengajak Masyarakat Melawan Kejahatan, LPPKS, Jakarta, 2009.

M. Abdul Kholiq. Buku Pedoman Kuliah Hukum Pidana, Fakultas Hukum Universitas Islam Indonesia. Yogyakarta. 2002.

M.Sudradjat Bassar. Tindak-Tindak Pidana Tertentu di Dalam Kitab UndangUndang Hukum Pidana.

$\begin{array}{lll}\text { Remadja } & \text { Karya; } & \text { Bandung. }\end{array}$

Muhadar, Viktimisasi Kejahatan Pertanahan, LaksBang PRESSindo, Yogyakarta,

2006.

Muhammad Tahir Azhary, Negara Hukum: Suatu Studi tentang PrinsipPrinsipnya Dilihat dari Segi Hukum Islam, Implementasinya pada Periode Negara Madinah dan Masa Kini, Bulan Bintang, Jakarta, 1992 


\section{Jumal Negara dan $\mathcal{X}$ eadilan \\ p-ISSN 2302-7010 e-ISSN 2721-9801}

Ninik Widiyanti dan Yulius Waskita, Kejahatan dalam masyarakat dan pencegahannya. Bima Aksara, Jakarta, 1987.

\section{Jurnal}

B. Arief Sidharta, "Kajian Kefilsafatan tentang Negara Hukum", dalam Jentera (Jurnal Hukum), "Rule of Law", Pusat Studi Hukum dan Kebijakan (PSHK), Jakarta, edisi 3 Tahun II, November 2004 